\title{
Import of Institutions as an Approach to Investment Climate Reform: Evidence from Russia
}

\begin{abstract}
By Alexander Pakhalov*
Institutional quality has a significant impact on indicators of investment activity both at the national and regional level. Studies show that regions of Russia with a more favorable institutional environment attract more foreign direct investements (FDI). In 2012 the Russian government introduced the reform package called the Regional Investment Standard that involves import of economic institutions and best investment climate practices from the advanced regions of Russia to the less developed ones. This paper aims to provide an empirical assessment of the effectiveness of the Regional Investment Standard. The study is based on a unique dataset collected during a series of polls and structured interviews with investors and government officials in nine Russia's regions. The results of the study show that reduction of administrative barriers for investors is the most significant result of this reform package. However, the Regional Investment Standard does not have any positive impact on the level of investors' rights protection and does not create the necessary tax incentives for investors. We consider it expedient to create for each region an individual reform plan in the form of supplement to the Regional Investment Standard. It is also necessary to organize at the federal level a system of stimulating and monitoring the implementation of reforms. (JEL H77, P48, R58)
\end{abstract}

Keywords: Import of Institutions, Investment Climate Reforms, Russia's Regions, Regional Investment Standard.

\section{Introduction}

Investment is one of the most important sources of economic growth for countries and their regions. There are disproportions in the distribution of investment among different territories. According to the United Nations Conference on Trade and Development (UNCTAD), in 2017 FDI in European Union countries accounted for more than $24 \%$ of the global inflow of FDI, while the share of FDI in all African countries was about 3\% (Global Investment Trends Monitor 2018).

Studies show there is a fairly close relationship between the growing investment and the rapid economic development. Researches linked rapid growth of China's economy to the increased investment activity in the country (Yao 2006, $\mathrm{Qu}$ et al. 2017). At the same time, the majority of African countries have low investment levels and their economies are stagnating or suffering from recession (Bissoon 2011).

\footnotetext{
*Researh fellow, Co-Head of Marketing Master's Program, Lomonosov Moscow State University, Russia.
} 
Various empirical studies conducted in Russia, Eastern Europe, China and other countries show the important role of investment in regional economic development. In particular, foreign direct investment has a positive effect on economic growth, labor productivity and the development of innovation (Dairabayeva et al. 2016, Hafner and Kleinert 2018, Iwasaki and Suganuma 2015).

Russia's regions have significant differences in the level of investment activity (Ledyaeva 2009). In the first six months of 2018, Moscow received about half $(45.4 \%)$ of the total inflow of FDI in Russia. At the same time, the whole North Caucasus Federal District had less than $0.1 \%$ of the total inflow of FDI to Russia (see Figure 1).

Figure 1. Share of Regions in Total FDI Inflow to Russia, January-June 2018

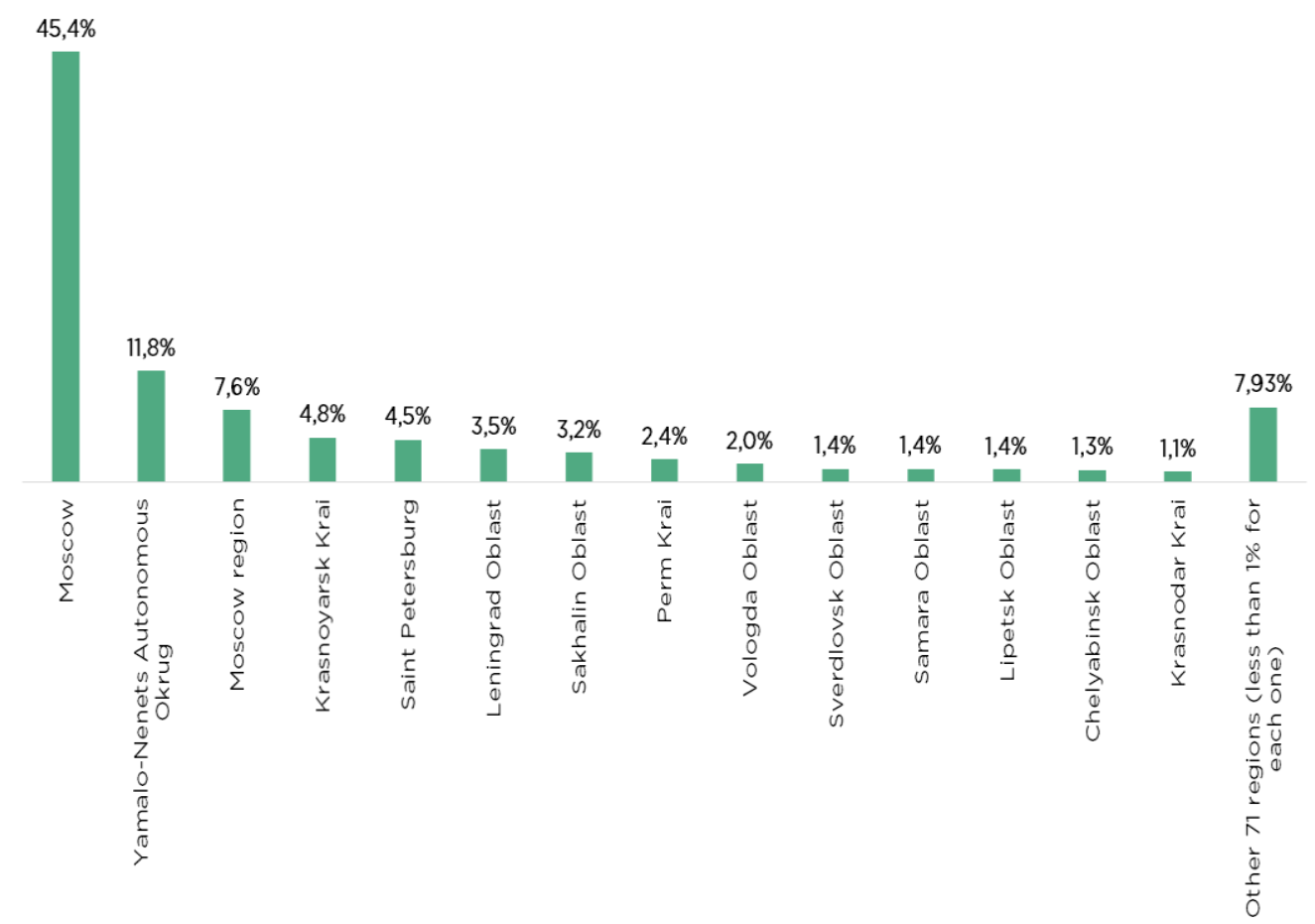

Source: Author's estimates based on data by the Central Bank of Russia.

Levels of investment activity in the regions of Russia do not seem to be determined only by geographical, climatic, or infrastructural conditions. Another important factor explaining the differentiation of investment activity is the quality of institutions: investors are looking for regions with more predictable and fair "rules of the game" that govern state-business relations (Leonard et al. 2016, Pinskaya et al. 2016).

Thus, Kaluga region, about $200 \mathrm{~km}$ to the south of Moscow, has been successfully attracting foreign investment since the early 2000s (Zimin 2010). At the same time Ivanovo region, having similar geographical location, attracts next to zero FDI and is one of the investment outsiders (see Figure 2).

This difference can be caused by a number of specific (and statistically unobservable) factors that influence investment climate in each particular region. 
An important unobservable factor that determines investment climate in a region is the quality of its institutional environment (Doing Business in Russia 2012).

Figure 2. Regional Investment Imbalances in Central Russia's Regions

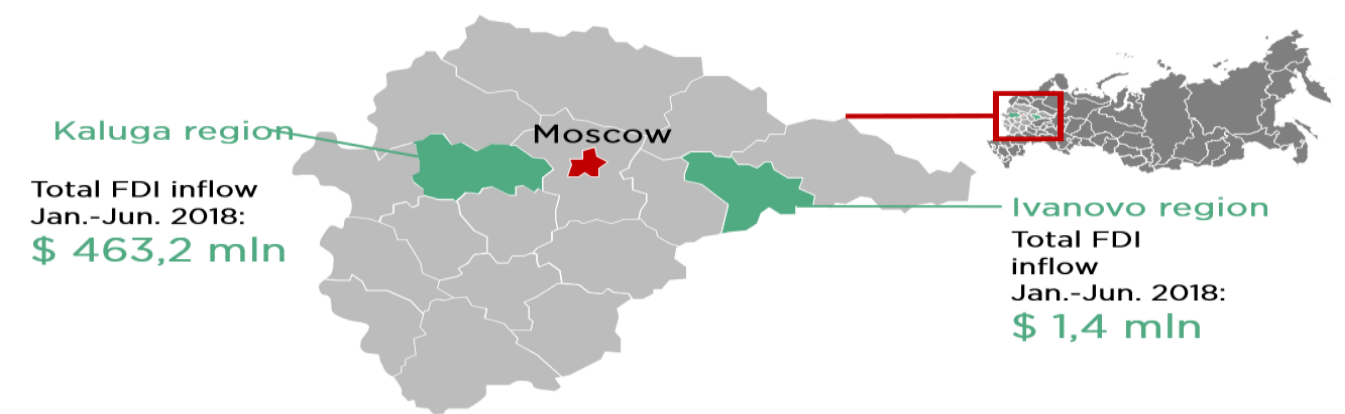

Source: Author's estimates based on data by the Central Bank of Russia.

This paper aims to provide an empirical assessment of the effectiveness of the Regional Investment Standard. The rest of the paper is organized as follows: first, we give a short review of literature on investment climate and its institutional determinants; having then briefly described the Regional Investment Standard, we explain the methodology of our research, present our findings and conclude with discussion and directions for future research.

\section{Literature Review}

In 2002 Stern described investment climate as "policy, institutional and behavioural environment, both present and expected, that influences the returns and risks, associated with investment" (Stern 2002). This definition was expanded in the well-known World Bank report where investment climate was defined as a set of factors that "provide opportunities and incentives for firms to invest productively, create jobs, and expand" (World Development Report 2005: 1). In this report, the World Bank experts also focused on institutions as an essential part of investment climate.

Better institutions are believed to help attract investment (North 1990, Dawson 1998). The recent literature (Smith and Hallward-Driemeier 2005) identifies three channels of institutional impact on investment activity:

1) the influence of institutions on investment project risks;

2) the influence of institutions on investment project costs;

3) the influence of institutions on barriers to competition.

Investment climate is determined by both formal and informal institutions that regulate the processes of investing and doing business at initial and subsequent stages. The two key institutional factors of investment climate are contracting institutions and property rights institutions (Acemoglu and Johnson 2005, Linz 2002). In some papers, taxation system is also included in the list of institutions that are important for investors (Kinda 2018, Tuomi 2011). 
Many empirical studies have shown that the quality of institutions has a significant impact on investment activity indicators both at the country level (Knack and Keefer 1995, Batra et el. 2003, Alguaci et al. 2011, Bissoon 2011) and at the regional level (Dollar et al. 2003, Ma 2006, Leonard et al. 2016, Iammarino 2018). According to these studies, well-functioning institutions reduce risks for investors, improve business conditions and help attract foreign direct investment.

Some policymakers and their economic consultants believe that business conditions in the problem regions can be improved by introducing the best practices which helped successful regions to attract investment. The new institutional economic theory calls this approach import of institutions (Bermeo 2002). Imports of institutions were usually discussed in the economic literature in the context of borrowing constitutional and political institutions from one country to another (Weingast 1993, Acemoglu et al. 2001, Banerjee and Iyer 2005).

There is practically no literature on the import of institutions at the regional level. At the same time, this approach is used in practice. For example, this approach lies at the heart of the document Regional Investment Standard which outlines reforms currently implemented in all Russia's regions at the initiative of the federal government.

\section{The Regional Investment Standard as a Tool for Import of Institutions}

The current stage of investment climate reforms in Russia began in the early 2010s. The reforms were partly driven by a number of investment climate surveys (including subnational report "Doing Business in Russia 2012" and "Enterprise Surveys Russia 2012") that showed significant regional differences in the quality of institutions. In some regions the quality of institutions corresponded to the best international practices, while in others poorly functioning institutions and regulatory standards seriously impeded business activity.

The federal government decided to eliminate these imbalances through a reform package aimed at importing best institutions from the most developed regions to the less developed ones. This package, prepared by the Agency for Strategic Initiatives (Russian investment promotion agency), was entitled the Standard for regional executive authorities to ensure a favorable investment climate in the region" (or simply the Regional Investment Standard).

The Regional Investment Standard is a set of institutional, infrastructural and other reforms aimed at attracting investment to Russia's regions and at improving the overall investment climate in the country. Since 2013 the implementation of this standard became mandatory for all regions of Russia. Figure 3 shows the structure of the Regional Investment Standard. 
Figure 3. Regional Investment Standard

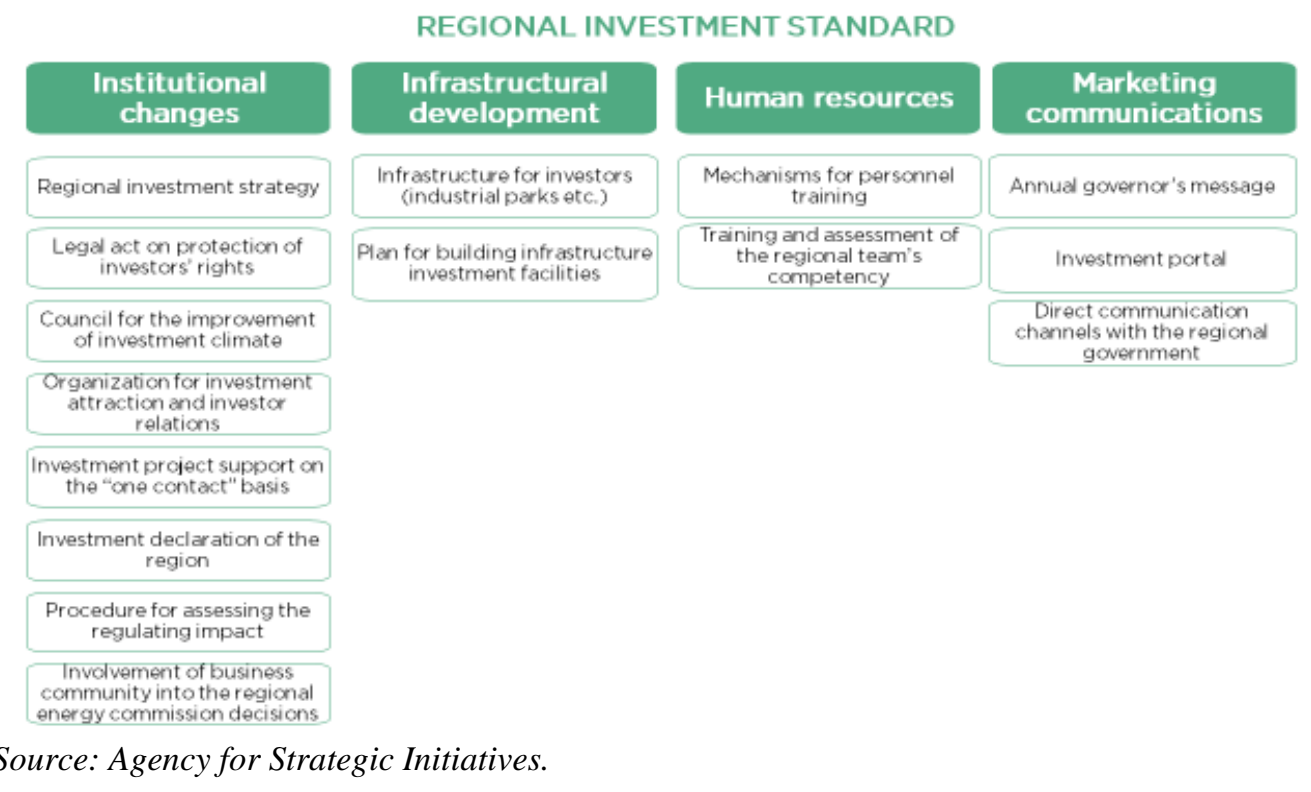

Eight out of fifteen requirements of the Regional Investment Standard relate to institutional changes in the regions. They concern either creation of the new institutions or changes to one or several components of the existing institutions. Regional governments are expected to carry out the following measures:

1) to develop a regional investment strategy;

2) to adopt a regulatory act aimed at protecting investors' rights and developping investment support mechanisms;

3) to create a council for improving investment climate in the region, functioning on a regular basis;

4) to create a specialized body responsible for attracting investment and working with investors in the region;

5) to develop regulations for the support of all categories of investment projects, within which a full range of support tools is provided at all stages of business development on the single-window system;

6) to adopt a regional investment declaration spelling out the principles of interaction between government authorities, business, and investment organisations;

7) to adopt a regional legal act on the procedure of regulatory impact assessment;

8) to involve members of business communities into regional energy comission decisions.

The remaining requirements of the Standard concern the management, infrastructure, image and personnel decisions that can help attract investors to the regions. For example, one of such requirements involves designing and publishing plans to build objects of infrastructure or create a regional information website for investors in Russian and other languages. 
By the end of 2014, the Regional Investment Standard was fully implemented in most regions of the country. Since 2016, after the publication of statistical materials and ratings assessing the changes in the investment climate of Russia's regions, experts and researchers have the opportunity to evaluate the effectiveness of the implementation of this reform package.

In the materials published by the Agency for Strategic Initiatives (the developer of the Standard) and the Ministry of Economic Development of the Russian Federation (the federal authority responsible for implementation of programs to improve the investment climate at the federal and regional levels), the results of the implementation of the Standard are considered to be positive. The improvement of Russia's position in the global ranking of business conditions "Doing Business" is often referred to as evidence of the effectiveness of the Standard (Figure 4).

Figure 4. Russia's Ranks in Doing Business Ranking, 2014-2018

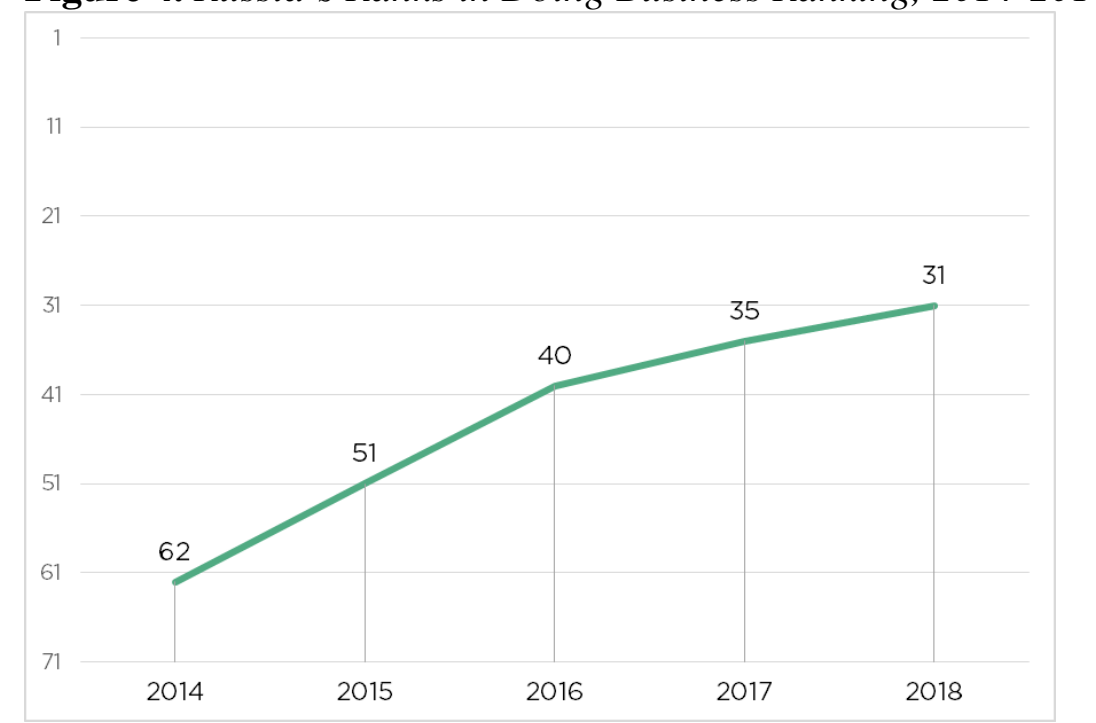

Source: Historical Data Sets and Trends Data / Doing Business / World Bank.

However using the Doing Business global rating as an indicator of performance does not seem entirely correct. The fact is that this rating takes into account only two of the Russia's regions - Moscow and St. Petersburg. The improvement in the investment climate of these regions does not mean that all other regions where the Standard was implemented have achieved same or similar results.

A gradual reduction in the regional investment imbalances could be a convincing proof of the effectiveness of the Standard as a tool for disseminating best practices and aligning the quality of investment climate in the regions. However, the variance analysis of the statistical data (see Table 1) does not confirm the existence of such a trend: in 2014-2017 - the four years of operation of the Standard - the level of regional differentiation in terms of investment activity remained high. 
Table 1. FDI Regional Distribution

\begin{tabular}{|c|c|c|c|c|}
\hline Year & Average & Median & St. Deviation (SD) & $\begin{array}{c}\text { Coefficient of Variation } \\
\text { (CV) }\end{array}$ \\
\hline 2014 & $1,685.07$ & 170.96 & $8,552.66$ & 5.08 \\
\hline 2015 & $1,565.27$ & 177.19 & $7,349.60$ & 4.70 \\
\hline 2016 & $1,611.83$ & 148.70 & $7,240.34$ & 4.49 \\
\hline 2017 & $1,759.72$ & 178.69 & $9,318.05$ & 5.30 \\
\hline
\end{tabular}

Source: Author's estimates based on data by the Central Bank of Russia.

In the first half of 2018, there were no changes in investment distribution among regions: again, about half of the total inflow of foreign direct investment went to Moscow; among other leaders in attracting investment remained the "oil and gas" regions (Tyumen and Sakhalin regions, Yamalo-Nenets Autonomous Region) and the largest megacities (St. Petersburg and Moscow region). The third group of leaders included the regions that had significantly improved their investment climate before the introduction of the Regional Investment Standard, for example, Kaluga, Belgorod and Leningrad regions.

We conducted an empirical study to evaluate the effectiveness of implementing the Standard in the regions, identify problems that arose in the process and suggest ways to solve these problems.

\section{Methodology}

The data from nine regions of the Russian federation allowed us to evaluate the effectiveness of the Regional Investment Standard and to identify key factors limiting the success of this reform program. The study included investor surveys and structured interviews with investors and representatives of the authorities of each of these regions. The design of the study is shown in Figure 5.

Figure 5. Design of the Empirical Study

9 RUSSIA'S REGIONS
$\begin{gathered}\text { Regional \& } \\ \text { local } \\ \text { authorities } \\ \text { region, Tomsk region, Pskov region, Tatarstan }\end{gathered}$
$\begin{gathered}\text { - What do you think about the "Standard" } \\ \text { implementation in your region? } \\ \text { - What has changed for the better? } \\ \text { - What needs to be changed? }\end{gathered}$

Source: Author's empirical survey. 
The empirical research was based on the use of two methods: surveys (for investors) and structured interviews (for investors and regional authorities). A detailed description of each of these methods is below.

\section{Poll Methodology}

The quality of investment climate perceived by investors was assessed on the basis of a questionnaire (see Appendix 1), in which respondents were asked to evaluate several parameters of the regional investment climate. The respondents were offered six statements to agree or disagree with:

- Business conditions in my region are improving

- Regional authorities sufficiently protect investors' rights

- Courts and law enforcement system sufficiently protect investors' rights

- Regional authorities provide support in the implementation of my investment project

- I am satisfied with time and cost of the procedures required for connecting to infrastructure (e.g. water, energy)

- I am satisfied with time and cost of the procedures required for starting a business (e.g. licensing)

For each item of the questionnaire, the diffusion index is calculated by the formula:

$$
D I_{i}=-1 \cdot \text { Share }_{\text {disagree }}+1 \cdot \text { Share }_{\text {agree }}
$$

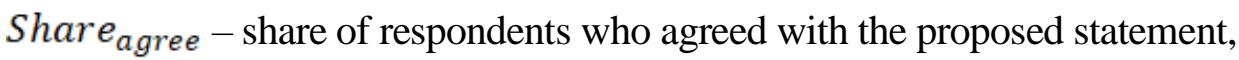
Share $_{\text {disagree }}$ - proportion of respondents who disagreed with the proposed statement.

Thus, a higher value of the diffusion index corresponds to a more favorable state of a particular parameter of investment climate, and a lower value to a less favorable state.

\section{Interview Methodology}

Structured interview is a key method of our research. Recently, structured and semi-structured interviews (as well as some other methods of qualitative research) are actively used in the studies of investment climate (Alcantara and Woolcock 2014). Interviews with investors help to explore the features of investment climate in countries (Tuomi 2011) and industries (Leete et al. 2013).

In most qualitative studies of investment climate, only investors and entrepreneurs act as interview participants (Tuomi 2011, Ershova 2017). However, this approach ignores the opinion of government officials who are responsible for shaping this climate. Their incentives and motives significantly determine the quality of the institutional reforms they are conducting. That is why this empirical 
study uses structured interviews with two categories of respondents - investors and representatives of regional authorities.

\section{Interview Questions for Investors:}

- What, in your opinion, have been the most significant changes in the investment climate of the region in recent years?

- What difficulties has your company faced in the process of project implementation in the region $X$ ? In your opinion, is it possible to solve the problems you have indicated? How can it be done?

Interview questions for the authorities:

- What are the most significant changes that occurred after the implementation of the Regional Investment Standard in your region?

- What difficulties have you faced in the implementation of the Regional Investment Standard in your region?

All interviews were decrypted and processed (as text files) using content analysis in the QDA Data Miner software package.

\section{Data Description}

Data collection for the study was carried out between April 2015 and April 2017 in nine regions of Russia: Vladimir Oblast, Kaliningrad Oblast, Kaluga Oblast, Leningrad Oblast, Lipetsk Oblast, Magadan Oblast, Pskov Oblast, Tomsk Oblast and the Republic of Tatarstan. The sample of the study is described in Table 1 . All respondents were guaranteed complete confidentiality and anonymity of the information collected.

We conduct a survey of representatives of companies implementing investment projects in the territory of each of the regions. The main task of the survey was to find out how investors see the general state of investment climate in the region. Moreover, we conducted in each region structured interviews with one, sometimes two, major investors from the group of respondents. The objectives of the structured interviews were to study in greater depth the attitude of investors to the institutional environment and investment climate of the regions.

Opinions of the representatives of regional authorities were also studied using structured interviews. For each region included in the study, respondents were selected from among the heads and deputy heads of the department (ministry) responsible for attracting investments (see Table 2). 
Table 2. Research Sample

\begin{tabular}{|l|c|c|c|}
\hline Region & $\begin{array}{c}\text { Number of Poll } \\
\text { Respondents } \\
\text { (Response Rate) }\end{array}$ & $\begin{array}{c}\text { Number of } \\
\text { Interview } \\
\text { Participants } \\
\text { (Investors \& } \\
\text { Business) }\end{array}$ & $\begin{array}{c}\text { Number of } \\
\text { Interview } \\
\text { Participants } \\
\text { (Regional } \\
\text { Authorities) }\end{array}$ \\
\hline Vladimir region & $25(43 \%)$ & 2 & 1 \\
\hline Kaliningrad region & $13(37 \%)$ & 1 & 1 \\
\hline Kaluga region & $11(37 \%)$ & 1 & 1 \\
\hline Leningrad region & $19(48 \%)$ & 2 & 1 \\
\hline Lipetsk region & $12(31 \%)$ & 1 & 1 \\
\hline Magadan region & $14(50 \%)$ & 1 & 1 \\
\hline Tomsk region & $18(49 \%)$ & 2 & 1 \\
\hline Tatarstan & $15(28 \%)$ & 1 & $\mathbf{9}$ \\
\hline Pskov region & $14(30 \%)$ & 1 & 1 \\
\hline Total & $\mathbf{1 4 1 ( 3 8 \% )}$ & $\mathbf{1 2}$ & 1 \\
\hline
\end{tabular}

Source: Author's empirical survey.

\section{Investor Poll Findings}

Diffusion indexes for all items of the questionnaire are presented in Table 3. In all the regions, the majority of investors agreed with the statement that the investment climate was improving. At the same time, some of the investment climate parameters remained far from desirable.

In four of the nine regions (Vladimir, Lipetsk, Pskov, and Tomsk regions) diffusion indexes for all particular parameters of investment climate had negative or zero values. This means that most investors do not expect their rights to be protected and consider administrative procedures that accompany the process of implementing investment projects to be unsatisfactory.

In Kaliningrad region, a negative value of only one diffusion index was recorded, which means that the project received a fair amount of support from the regional authorities. In Leningrad and Tomsk regions, the negative values of the diffusion index were also recorded for the protection of investors' rights by the courts and law enforcement system. This may be explained by the fact that the law enforcement agencies are not subordinated to the regional authorities.

Only in two regions (Tatarstan and Kaluga region) all diffusion indexes of investment climate had positive values. Both of these regions were sources of the best institutional practices for the Regional Investment Standard, and, therefore, have been involved in the export of institutions and investment climate rather than import. 
Table 3. Diffusion Indexes for Parameters of Investment Climate

\begin{tabular}{|c|c|c|c|c|c|c|c|c|c|}
\hline Questions & 氖 & ס & 勇 & 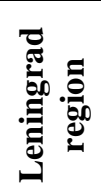 & 苋 & 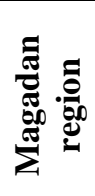 & 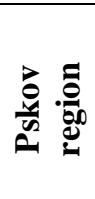 & 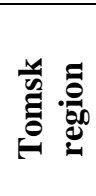 & 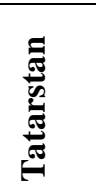 \\
\hline $\begin{array}{l}\text { Business } \\
\text { conditions in my } \\
\text { region are } \\
\text { improving }\end{array}$ & +0.24 & +0.54 & +0.73 & +0.58 & +0.17 & +0.21 & +0.29 & +0.44 & +0.60 \\
\hline $\begin{array}{l}\text { Regional } \\
\text { authorities } \\
\text { sufficiently } \\
\text { protect investors' } \\
\text { rights }\end{array}$ & -0.28 & +0.08 & +0.64 & +0.05 & -0.33 & -0.29 & -0.29 & +0.11 & +0.47 \\
\hline $\begin{array}{l}\text { Courts and law } \\
\text { enforcement } \\
\text { system } \\
\text { sufficiently } \\
\text { protect investors' } \\
\text { rights }\end{array}$ & -0.20 & +0.23 & +0.09 & -0.05 & -0.33 & -0.29 & -0.43 & -0.22 & +0.07 \\
\hline $\begin{array}{l}\text { Regional } \\
\text { authorities } \\
\text { provide support in } \\
\text { the } \\
\text { implementation of } \\
\text { my investment } \\
\text { project }\end{array}$ & -0.28 & -0.23 & +0.45 & -0.16 & -0.50 & -0.43 & -0.57 & -0.22 & +0.07 \\
\hline $\begin{array}{l}\text { I am satisfied } \\
\text { with time and cost } \\
\text { of the procedures } \\
\text { required for } \\
\text { connecting to } \\
\text { infrastructure } \\
\text { (e.g. water, } \\
\text { energy) }\end{array}$ & -0.44 & +0.08 & +0.45 & +0.58 & -0.17 & -0.43 & 0.00 & -0.11 & +0.33 \\
\hline $\begin{array}{l}\text { I am satisfied } \\
\text { with time and cost } \\
\text { of the procedures } \\
\text { required for } \\
\text { starting a business } \\
\text { (e.g. licensing) }\end{array}$ & -0.12 & +0.38 & +0.64 & +0.26 & -0.17 & -0.29 & -0.14 & 0.00 & +0.20 \\
\hline
\end{tabular}

Source: Author's empirical survey.

\section{Investor Interview Findings}

Interviews with major investors were conducted in order to assess more accurately the quality of investment climate in the regions. We also wanted to understand how investors evaluate the results of regional investment climate reforms. Table 4 shows the most frequent answers of the investors to the question about the main changes in their region's investment climate in recent years. 
Table 4. Investment Climate Changes Mentioned in Investor Interviews

\begin{tabular}{|l|c|}
\hline Types of Changes & Mentioned in \% of Interviews \\
\hline Lower administrative barriers & $58.30 \%$ \\
\hline Increased openness and transparency of authorities & $41.70 \%$ \\
\hline New infrastructure for investors & $25.00 \%$ \\
\hline Increased risk of corruption & $16.70 \%$ \\
\hline No changes & $8.30 \%$ \\
\hline
\end{tabular}

Source: Author's empirical survey.

Lower administrative barriers, greater openness of those in power and the development of investment infrastructure are among the most significant changes noted by the respondents. All these positive changes may have resulted from the implementation of the Regional Investment Standard. At the same time, a number of investors are very skeptical about the changes. One respondent says: "The most noticeable change is probably an increase in the declared openness of the regional authorities. It was declared, but in reality it hasn't become easier to get through to the administration."

In two interviews, a negative change in the investment climate was noted - an increase in corruption risks. This phenomenon is not related to the use of Regional Investment Standard and can be explained by several high-profile corruption scandals in the regions (Dininio and Orttung 2005).

Attempts to carry out investment projects in the regions are still associated with a number of difficulties for investors. During the interview, the respondents were asked questions about difficulties in running investment projects and possible institutional mechanisms for overcoming these difficulties (see table 5). Their answers help to understand which institutional changes are most needed by investors.

Table 5. Investment Climate Challenges Metioned in the Investors' Interviews

\begin{tabular}{|l|c|}
\hline Types of Challenges & Mentioned in \% of Interviews \\
\hline High tax burden & $41.70 \%$ \\
\hline Low investor protection & $41.70 \%$ \\
\hline Infrastructural problems & $16.70 \%$ \\
\hline Poor work of local (cities') authorities & $25.00 \%$ \\
\hline Administrative barriers & $25.00 \%$ \\
\hline International trade difficulties (export/import) & $8.30 \%$ \\
\hline No challenges & $8.30 \%$ \\
\hline
\end{tabular}

Source: Author's empirical survey.

The greatest difficulties for investors are related to the tax burden and inspections by tax authorities. In particular, a respondent from Lipetsk region notes: "The tax system should become more business friendly. There must be fewer checks and fines, this is a very negative factor." These results differ from the empirical results for other developing countries: in particular, a recent study on African countries (Kinda 2018) showed that tax institutions have less influence on the investor's choice compared to other institutional factors. 
The results of the interviews also show that the Regional Investment Standard is not able to completely solve the problem of low protection of investors' rights. More than a third of investors do not feel protected and demand better protection of their rights and results of their investments. Regional authorities cannot be effective guarantors of the investor protection institutions in conditions of poor quality of courts and the law enforcement system. The respondent from Vladimir region notes that "the court system should become fairer, businesses should have at least some chance of winning in disputes with the state structures."

\section{Regional Authorities Interview Findings}

Structured interviews with representatives of the regional authorities were aimed at identifying the features and difficulties that they face in the process of implementing the Regional Investment Standard. Table 6 presents the most frequent answers of the regional officials to the question about the main changes that have occurred in their regions as a result of the Regional Investment Standard implementation.

Table 6. Investment Climate Changes Metioned in Authorities' Interviews

\begin{tabular}{|l|c|}
\hline Types of Changes & Mentioned in \% of Interviews \\
\hline Better communication with investors & $55.60 \%$ \\
\hline Reduction of administrative barriers/one window & $44.40 \%$ \\
\hline Improvement of existing laws and rules & $44.40 \%$ \\
\hline Experience exchange with other regions & $22.20 \%$ \\
\hline Promotion of competition & $11.10 \%$ \\
\hline
\end{tabular}

Source: Author's empirical survey.

The answers of the representatives of the regional authorities, in general, match up with investors' answers to the question. Some local officials also frequently referred to the results associated with lowering barriers and building a dialogue with the business community through the introduction of a singlewindow system and direct communication channels between investors and authorities.

Table 7. Regional Investment Standart Challenges Metioned in Authorities' Interviews

\begin{tabular}{|l|c|}
\hline Types of Challenges & Mentioned in \% of Interviews \\
\hline Lack of necessary tools to attract investors & $55.60 \%$ \\
\hline $\begin{array}{l}\text { Inability to take into account the specific features } \\
\text { of the region }\end{array}$ & $44.40 \%$ \\
\hline Problems at the local level (cities) & $44.40 \%$ \\
\hline Lack of competence and motivation of officials & $33.30 \%$ \\
\hline No challenges & $33.30 \%$ \\
\hline
\end{tabular}

Source: Author's empirical survey. 
We also asked the representatives of the regional authorities to identify the difficulties encountered in the implementation of the Regional Investment Standard. The results of processing the answers to this question are presented in table 7.

More than half of the interview participants noted that the Regional Investment Standard does not contain the full range of tools needed to attract investors. Moreover, many respondents pointed out that the reform package ignored regional specifics.

Problems at the municipal level are another significant barrier to the implementation of the Regional Investment Standard. A representative of regional administration notes, "There is often just not enough experience with investors in cities. We understand this well, so we try to take some issues to the regional level." The leaders of some Russian regions are taking concrete measures to overcome institutional inertia at the municipal level. In particular, in Leningrad Region, a project is undertaken to introduce the "Municipal Investment Standard", which promotes reforms at the city level. The results of the interview also show that some of the difficulties in reform implementation are related to the lack in motivation of regional and local authorities. The roots of such difficulties vary depending on the type of the region. In some resource-based regions, policymakers believe that natural resources will help them find investors, even with bad institutions. In the regions with strong informal institutions policymakers say that "it makes no sense to change formal institutions (laws), since informal institutions (traditions and customs) are stronger". In some other regions authorities still believe that it is easier to give special preferences to some of the large investors than to improve investment climate in general.

\section{Conclusion}

Import of institutions at the regional level within the framework of the Regional Investment Standard has so far yielded controvesial results. The greatest achievement is the introduction of the mechanisms to lower administrative barriers through the use of single-window system. At the same time, the Regional Investment Standard does not seem to have solved the problems connected with attracting investors. In particular, the ongoing reforms have not apparently had a positive impact on the institutions protecting the rights of investors and have not helped to form tax mechanisms supporting investment projects.

One of the possible explanations for problems with these investment climate reforms is related to the fact that the established institutional environment of the particular region can influence the success of the new instituttion's introduction. In such cases, it is possible to talk about the path dependence problem (Martin and Sunley 2006), implying the impossibility of some institutional changes in the current institutional environment of this particular region.

We consider it expedient to create for each region an individual reform plan in the form of supplement to the Regional Investment Standard. These additions may 
include regulations that take into account the features of the particular region such as the structure of its economy, the role of small business, and geographic location.

It is also necessary to organize at the federal level a system of stimulating and monitoring the implementation of reforms. The federal government also needs to think about reforming regional courts and law inforcement agencies. Attempts to improve regional investment climate without institutional changes at the national level resemble using an umbrella instead of repairing the leaking roof. Institutional changes at the regional level should be accompanied by reforms at the national (country) and local (cities) levels.

Outside the scope of this study were questions about the specific channels of the influence of the regional institutional environment on the success of investment climate reforms. These questions are promising areas for further research.

\section{References}

Acemoglu D, Johnson S (2005) Unbundling institutions. Journal of Political Economy 113(5): 949-995.

Acemoglu D, Johnson S, Robinson JA (2001) The colonial origins of comparative development: An empirical investigation. American Economic Review 91(5): 13691401.

Alguacil M, Cuadros A, Orts V (2011) Inward FDI and growth: The role of macroeconomic and institutional environment. Journal of Policy Modeling 33(3): 481-496.

Banerjee A, Iyer L (2005) History, institutions, and economic performance: The legacy of colonial land tenure systems in India. American Economic Review 95(4): 1190-1213.

Batra G, Kaufmann D, Stone AH (2003) Investment Climate Around the World: Voices of the Firms from the World Business Environment Survey. The World Bank. Available at: https://bit.ly/31iYcXA.

Bermeo NG (2002) The import of institutions. Journal of Democracy 13(2): 96-110.

Bissoon O (2011) Can better institutions attract more foreign direct investment (FDI)? Evidence from developing countries. In International Conference on Applied Economics (pp. 59-70). Available at: https://bit.ly/2IssIG5.

Dairabayeva K, Ferrantino MJ, Portugal-Perez A, Schmidt G (2016) Export Competitiveness and FDI Performance Across the Regions of the Russian Federation. The World Bank. Available at: https://bit.ly/2Zhp8VU.

Dawson JW (1998) Institutions, investment, and growth: New cross-country and panel data evidence. Economic Inquiry 36(4): 603-619.

Dininio P, Orttung R (2005) Explaining patterns of corruption in the Russian regions. World Politics 57(4): 500-529.

Dollar D, Hallward-Driemeier M, Shi A, Wallsten S, Wang S, Xu LC (2003) Improving the investment climate in China. Investment Climate Assessment: World Bank and International Finance Corporation. Available at: https://bit.ly/2I2zZxc.

Ershova N (2017) Investment climate in Russia and challenges for foreign business: The case of Japanese companies. Journal of Eurasian Studies 8(2): 151-160.

Hafner KA, Kleinert J (2018) FDI Flows and regional development: lessons for transition countries. In J Ateljević, J Budak (eds) Entrepreneurship in Post-Communist Countries, 47-59. Cham, Switzerland: Springer International Publishing. 
Iammarino S (2018). FDI and regional development policy. Journal of International Business Policy 1(3-4): 157-183.

Iwasaki I, Suganuma K (2015) Foreign direct investment and regional economic development in Russia: an econometric assessment. Economic Change and Restructuring 48(3-4): 209-255.

Kinda T (2018) The quest for non-resource-based FDI: Do taxes matter?. Macroeconomics and Finance in Emerging Market Economies 11(1): 1-18.

Knack S, Keefer P (1995) Institutions and economic performance: cross-country tests using alternative institutional measures. Economics \& Politics 7(3): 207-227.

Ledyaeva S (2009) Spatial econometric analysis of foreign direct investment determinants in Russian regions. World Economy 32(4): 643-666.

Leete S, Xu J, Wheeler D (2013) Investment barriers and incentives for marine renewable energy in the UK: An analysis of investor preferences. Energy Policy 60: 866-875.

Leonard CS, Nazarov Z, Vakulenko ES (2016) The impact of sub-national institutions: Recentralization and regional growth in the Russian Federation (2001-2008). Economics of Transition 24(3): 421-446.

Linz S (2002) Barriers to Investment by Russian Firms: Property Protection or Credit Constraints? (No. 469). William Davidson Institute at the University of Michigan.

Ma AC (2006) Geographical location of foreign direct investment and wage inequality in China. World Economy 29(8): 1031-1055.

Martin R, Sunley P (2006) Path dependence and regional economic evolution. Journal of Economic Geography 6(4): 395-437.

Alcántara AM, Woolcock M (2014) Integrating Qualitative Methods Into Investment Climate Impact Evaluations. The World Bank. Available at: https://elibrary.world bank.org/doi/abs/10.1596/1813-9450-7145.

North DC (1990) Institutions, Institutional Change and Economic Performance. Cambridge: Cambridge University Press.

Pinskaya MR, Melnichuk MV, Frumina SV, Tikhonova AV (2016) Problems of creating a favorable investment climate in Russian regions. International Journal of Economics and Financial Issues 6(8S): 300-306.

Qu Y, Qu T, Wu Y (2017) The role of regional formal institutions and foreign direct investment in innovation in Chinese enterprises. Asia Pacific Business Review 23(1): 27-43.

Smith W, Hallward-Driemeier M (2005) Understanding the investment climate. Finance and Development 42(1): 40-43.

Stern N (2002) The Investment Climate, Governance, and Inclusion in Bangladesh. World Bank Office of the Senior Vice President, Development Economics, Washington, DC. Available at: https://bit.ly/2F16FoO.

Tuomi K (2011) The role of the investment climate and tax incentives in the foreign direct investment decision: Evidence from South Africa. Journal of African Business 12(1): 133-147.

Weingast BR (1993) Constitutions as governance structures: The political foundations of secure markets. Journal of Institutional and Theoretical Economics (JITE)/Zeitschrift für die Gesamte Staatswissenschaft 149(1): 286-311.

Yao S (2006) On economic growth, FDI and exports in China. Applied Economics 38(3): 339-351.

Zimin D (2010) Promoting investment in Russia's regions. Eurasian Geography and Economics 51(5): 653-668.

Doing Business in Russia (2012) The World Bank Group. Available at: http://www.doing business.org/en/reports/subnational-reports/russia. 
Enterprise Surveys data for the Russian Federation (2012) The World Bank Group. Available at: https://bit.ly/2WpP9p4.

Historical Data Sets and Trends Data/Doing Business/World Bank (2019). Available at: http://www.doingbusiness.org/en/custom-query.

Global Investment Trends Monitor (Series) (2018) Available at: https://bit.ly/2IOfYHI.

World development Report (2005) A Better Investment Climate for Everyone. The International Bank for Reconstruction and Development/The World Bank. Available at: https://openknowledge.worldbank.org/handle/10986/5987. 


\section{Appendix 1: Survey Questionnaire}

Dear respondent! Thank you for taking part in our research. It will take you no more than 10 minutes. Your answers are strictly confidential and will be used only for statistical analysis.

Specify the region in which you run a business or implement an investment project:

Indicate whether you agree or disagree with the statements below:

Q1. Business conditions in my region are improving

$\square$ agree $\square$ disagree

Q2. Regional authorities sufficiently protect investors' rights

$\square$ agree $\square$ disagree

Q3. Courts and law enforcement system sufficiently protect investors' rights

$\square$ agree $\square$ disagree

Q4. Regional authorities provide support in the implementation of my investment project

$\square$ agree $\square$ disagree

Q5. I am satisfied with time and cost of the procedures required for connecting to infrastructure (e.g. water, energy)

$\square$ agree $\square$ disagree

Q6. I am satisfied with time and cost of the procedures required for starting a business (e.g. licensing)

$\square$ agree $\square$ disagree

Please answer a few general questions about your business:

Q7. In what industry you do business?

Q8. How many employees work in your company (specify an approximate number)?

Q9. Is your company small or medium-sized enterprise?

$\square$ yes, small $\square$ yes, medium $\square$ no

Q10. Do foreign investors participate in your project?

$\square$ yes $\square$ no 